sciendo Порівняльна професійна педагогіка 9(1)/2019 Comparative Professional Pedagogy 9(1)/2019

DOI: $10.2478 /$ rpp-2019-0001

Postdoctoral Researcher of Pedagogy, Full Professor, TYMOFIY DESYATOV Bohdan Khmelnytskyi National University at Cherkasy Address: 81 Shevchenko Blvd., Cherkasy, 18031, Ukraine E-mail: desyatov50@ukr.net

\title{
ADAPTING MECHANISMS FOR MANAGING QUALITY OF PEDAGOGICAL EDUCATION IN UKRAINE TO INTERNATIONAL EDUCATIONAL STANDARDS: COMPARATIVE ANALYSIS
}

\begin{abstract}
The article proves that the influence of integration processes of the growth of the role of globalization requires the necessity of using and adapting international educational standards and criteria of assessing the quality in the field of national education. It is noted that contemporary European practice involves the development of culture of quality through the introduction of quality management. The emphasis is placed on the fact that in the conditions of the transformation of the socio-political system, the formation of a civil society and market relations in the process of entering our country into a single educational European space, the search for ways to ensure the quality of higher education and the creation of mechanisms for its management are updated. It is investigated that the complexity of creating quality management mechanisms is not only to coordinate the development of the concept at all levels of state government, but also to coordinate the views of various government institutions. It is emphasized that adaptation is considered as a two-way interdependent process of adapting education (institutions that teach) to the student's personality, as well as his active inclusion in the design of an adaptive informational-and-educational environment and the development of individual educational routes. It has been found out that the main tools for determining the quality are internal and external evaluation. It is emphasized that the mechanism of quality management, in addition to assessing the provision of educational services, i.e. the process of teaching itself, focuses on the effectiveness of the functioning of higher education, i.e. the assessment of a specialist's professional training. The necessity of participation of stakeholders (employers) in the system of management of quality of higher pedagogical education is emphasized.

Keywords: adaptation, management, stakeholders, management mechanism, competence, intellectual capital, international standards, monitoring, internal self-assessment, external independent assessment.
\end{abstract}

\section{АНОТАЦІЯ}

У статті доведено, що вилив інтеграчійних процесів зростання ролі глобалізаиії вимагають необхідність використання та адаптаиії міжнародних освітніх стандартів і критеріїв очінки якості у сфері наиіональної освіти. Зазначено, що сучасна європейська практика передбачає розвиток культури якості шляхом впровадження менеджменту якості. Акиентовано увагу на те, що в умовах трансформації суспільно-політичного устрою, формування громадського суспільства й ринкових відносин у прочесі входження нашої країни до єдиного освітнього європейського простору актуалізується пошук шляхів забезпечення якості вищої освіти, створення механізмів управління нею. Досліджено, що складність створення механізмів 
sciendo Порівняльна професійна педагогіка 9(1)/2019 Comparative Professional Pedagogy 9(1)/2019

управління якістю полягає не лише в тому, щоб скоординувати розробку концепції на всіх рівнях державного управління, а й у тому, щоб узгодити погляди різних державних відомств. Наголошено, щуо адаптація розглядається як двобічний взаємообумовлений прочес пристосування освіти (інституції, які навчають) до особистості студента, а також активного включення його в проектування адаптивного інформаційноосвітнього середовища та розроблення індивідуальних освітніх маршрутів. 3'ясовано, щзо основними інструментами визначення якості виступають оцінювання внутрішнє та зовнішнє. Підкреслено, щзо механізм менеджменту якості, окрім очінки надання освітніх послуг, тобто самого процесу навчання, акцентує увагу на результативності функціонування вищої школи, тобто оцінюванні професійної підготовки фахівия. Наголошено про необхідність участі стейкхолдерів (роботодавиів) у системі менеджменту якості вищої педагогічної освіти.

Ключові слова: адаптація, менеджмент, стейкхолдери, механізм управління, компетентність, інтелектуальний капітал, міжнародні стандарти, моніторинг, внутрішня самооцінка, зовнішня незалежна оцінка.

\section{INTRODUCTION}

The purposeful entry of Ukraine into the world community requires a comprehensive analysis of the leading areas of the evolution of modern educational practice. The influence of integration processes and the increasing role of globalization lay the need for the use and adaptation of international educational standards and criteria of assessing the quality in the field of national education. Ensuring high quality of education is one of the key principles and the cornerstone of building the European Higher Education Area. At the Ministerial Conference, held in May 2018 in Paris, European education leaders reaffirmed the importance of this task, and also committed themselves to "supporting the further development of the system of assurance of quality of the educational process".

Domestic pedagogical thought actively reconsiders the administrative heritage. After all, many classical issues, including quality management issues, are gaining new meaning. However, the Ukrainian system of pedagogical education, unfortunately, is not one of the leaders among the countries regarding the proper maintenance of the quality of the educational process. In this regard, observation and analysis of the assessment of European achievements as for assurance quality at the institutional, national and continental levels is undoubtedly valuable for Ukrainian research-and-teaching staff, which became the subject of our work.

\section{THE AIM OF THE STUDY}

Taking into account the relevance of the identified problem, the purpose of the study is to conduct a comprehensive analysis of the leading areas of the evolution of modern educational practice. The need to use and adapt European experience in ensuring the quality of education in the Ukrainian system of higher education is undeniable.

\section{THEORETICAL FRAMEWORK AND RESEARCH METHODS}

The problem of assuring the quality of education through the use and adaptation of international educational standards and criteria of assessing the quality in the field of national education is the subject of scientific research of domestic and foreign scholars such as N. Avshenyuk, A. Sbrueva, S. Dombrovsky, A. Chmil, M. Korovkin, T. Finikov, A. Vasylyev, V. Yuskayev, A. Krykliy, S. Kubatov, I. Musienko. In foreign pedagogy, the problems of ensuring the quality of education are described in the works of A. Schleicher, E. Voznitsky, R. Bennet, M. Cheng, L. Matei, H. Döbert et al. 
The comparative-and-search method was used in the study. We were able to identify the similarities and differences in determining the criteria of assessing the quality in the field of the national education and in education of the EU countries with the help of comparison.

\section{RESULTS}

Over the past few years, improving the quality of higher education has taken a leading role in ensuring the competitiveness of Ukraine's educational system and training personnel of relevant qualification. The influence of integration processes and growing of role of globalization cause the necessity of using and adapting international educational standards and criteria for assessing the quality in the sphere of national education. However, the difference in the potential and resource provision of higher education in Ukraine in comparison with developed countries does not allow speaking about equal approaches to the issues of improving the quality of education.

However, domestic pedagogical thought actively reconsiders the administrative heritage. After all, many classical issues, including education quality management issues gain new meaning. In the conditions of the transformation of the socio-political system, the formation of civil society and market relations in the process of entering our country into a common educational European space, the search for ways to ensure the quality of higher education, the creation of mechanisms for its management, evaluative technologies, adaptation to international standards are actualized.

The concept of adaptability, in a certain sense, can be considered to be the most general notion of Pedagogy. For example, V. V. Krayevsky and O. V. Khutorsky define the content of education as "pedagogically adapted social experience". It is education that helps to "enter life" and adapt to it. But in order to become a specific adapter, education should be adapted to the realities of human life, to its needs. Therefore, on the one hand, through education, a person's adaptation to the new conditions of his life and work is carried out, and on the other hand, the adaptation of the education itself to the life of specific people takes place.

Thus, adaptation is seen as a two-sided interdependent process of adapting education (institutions that teach) to the student's personality, as well as the active inclusion of it in the design of an adaptive informational-and-educational environment and the development of individual educational paths.

A characteristic feature of the educational system of Ukraine is the preservation of an administrative management system with a high level of centralization. This model involves certain mechanisms for the implementation of management functions.

Centralization of management leads to an increase in the economic mass of the education system, causing an increase of its inertia and makes the rapid adaptation to changing external conditions impossible. At the same time there is an inevitable decline in the quality of education, because its management mechanisms lose their adaptability and do not meet the specific requirements of the labor market. This is confirmed by the research conducted by Razumkov's center. It is emphasized that the absence of an effective mechanism for quality control hinders the normal regulation of the development of the education sector. The analysis of the factors affecting the quality of education (level of financing, human resources, informational, material and technical support), shows a tendency to its deterioration (The system of education, 2002, pp. 2-36).

Independent assessments of higher education activities, accreditation and other procedures are aimed only at determining how well the teaching process meets established 
sciendo Порівняльна професійна педагогіка 9(1)/2019 Comparative Professional Pedagogy 9(1)/2019

criteria and requirements. The obvious advantage of these mechanisms is the completeness and detailization of accreditation criteria and valuation indicators.

At the same time, the other aspect of the assessment of the quality of higher education is not taken into account, i.e. a result as a final stage of educational activity. The indicators used in domestic educational statistics record the percentage of graduates' employment, but do not reflect employers' and trained specialists' opinion, do not take into account the requirements of the labor market, do not give an objective picture of the shortcomings in the training of applicants for higher education, and therefore do not allow to influence the elimination of gaps.

Obviously, the mechanism for management of quality of higher education should cover two subsystems - the control of quality of educational services and the quality of the result. Each of them is characterized by its indicators, which should turn into final products - competence.

One of the tasks of transformations carried out in recent years in Ukraine is the formation of the educational system, aimed at innovative development. However, as the scientific analysis shows, discrepancy of "challenges of modern times" with traditional approaches to education management became apparent. The new management paradigm in education needs to be formed as a way of qualitative breakthrough in knowledge and awareness of essence of management as a means of accumulation and use of intellectual capital. All this forces us to look for new ways and mechanisms of modernizing educational management.

Therefore, in modern conditions, the task of developing managerial models and methods that provide the development of personality through the use of its potential in creative innovation processes is updated. Actually, the process of managing an establishment of education, based on updating the innovative potential of the subjects of education, is built entirely in a special, personally-oriented way, which, in its turn, defines the requirements for the construction of modern management systems in the context of humanitarian technologies.

It should be noted that increasing the competitiveness of higher education involves the use of market mechanisms for managing the educational sphere and the quality of higher education, which are accepted in international practice. S.M. Dombrovska (2013) emphasizes that for the successful confrontation in the competition at the market of educational services, the introduction of international standards ISO Series 9000 is necessary (p. 55).

The mechanisms of management of quality of higher pedagogical education, based on these standards, involve the establishment of requirements of interested parties on the quality of services provided, the creation of effective tools for improving operations and control. A. I. Chmil (2006) specifies the principles laid down in international standards and which are used to develop mechanisms of management of education quality. They include: targeting consumers (students); increasing the role of leadership in the system of management of education quality; the involvement of pedagogical staff in the functioning of the system of quality management through increasing their responsibility and interest in the results of their activities; a process approach that involves managing educational structures as business processes; a systematic approach that takes into account the interconnection and interaction of higher education sub-systems to achieve greater efficiency and effectiveness; continuous improvement, in particular through the introduction of advanced methods and technologies; making decisions on the basis of undoubted facts and information (p. 75). 
In addition to the international standards of the ISO series, the most common models of systems of quality management are models based on the principles of the business perfection model EFQM (European Foundation for Quality Management) and overall quality management model (TQM) (Total Quality Management).

Scientists rightly consider TQM as an approach to managing an organization, based on quality. At the same time, the fundamental principles are orientation towards the consumer, who defines the criteria for the quality of the goods and services he needs, and the involvement of the staff in achieving the goal (Korovkin, 2005, p. 63). Unlike the approaches used in the ISO and TQM standards, the EFQM business perfection model allows comparative analysis between different establishments of education. I. I. Musiyenko (2010) draws attention to the fact that the application of this model is based on the use of criteria of the results and capabilities of the higher education system, which involve the improvement of educational activities and raising the effectiveness of mechanisms for managing the educational system (p. 30).

In view of the above mentioned, it is possible to distinguish the basic principles that the quality management system of higher education should meet, namely:

- objectivity, i.e the use of actual and reliable source information, which is based on indicators that fully characterize the teaching process and the effectiveness of higher education, for the adoption of managerial decisions;

- efficiency, i.e. providing effective mechanisms that allow by improving the quality of education to ensure the correspondence of the qualification of graduates and the expectations of employers and increase the competitiveness of higher education in the international market of educational services;

- realism, i.e. the development of practical recommendations and the sequence of stages of implementation of educational policy in the field of improving the quality of training specialists;

- adaptability, i.e. the ability of mechanisms of management of the quality of higher education to flexibly respond to changes of external conditions, labor market requirements, and thus offset the negative impact of inertia of educational processes;

- versatility, i.e. the formation of a system based on international quality standards that enhances the role of leadership, the involvement of scientific-and-pedagogical staff in the functioning of the system, orientation towards consumers of educational services;

- productivity, i.e. obtaining data for analytical work on monitoring the process of training of graduates, planning activities in the field of education, drawing up forecast indicators for adjusting educational programs, assessing the effectiveness of the functioning of higher education.

It should be emphasized that the proposed mechanism of quality management, in addition to assessing the provision of educational services, i.e. the process of teaching itself, focuses on the effectiveness of the functioning of higher education, i.e. the assessment of a specialist's professional training.

The system of management of quality of education for the implementation of these functions involves a certain algorithm of the construction.

Thus, the first stage covers the collection of primary information through the monitoring and self-assessment of the activities of the educational establishment. Initial data are qualitative and quantitative indicators that characterize the processes of education and employment. The sources of data are Results of internal self-assessment of an educational establishment, materials of external independent evaluation, data of international and 
sciendo Порівняльна професійна педагогіка 9(1)/2019 Comparative Professional Pedagogy 9(1)/2019

domestic statistics, employment services, personnel units of enterprises, ratings, expert assessments, sociological surveys and other analytical materials.

The second stage involves analyzing and processing the received data, correlating the results with the directions of the policy of establishments of higher education as for the quality of scientific researches and defining the goals of management of quality of education, steps of their implementation. This stage determines the role of leadership in determining the priority tasks of improving quality, formulating goals and strategic directions for the development of an establishment of education. At the same time there is an engagement of scientific-and-pedagogical staff by using motivation mechanisms to achieve the goal: to ensure effective quality management.

In the third stage there is an audit of quality, which, as noted by a group of scientists (Korovkin, 2005, p. 68), serves as an integral part of the management system, a mechanism for improving quality and cost structure. Its main difference from the self-assessment procedure is the independence of the conduct. The purpose of the audit is to determine the effectiveness of functioning of mechanism of management of quality of education, its compliance with its objectives of training specialists. In this case, the activities of all subsystems of higher education are assessed according to the criteria of efficiency and effectiveness. This work is carried out with the assistance of independent experts, who should include representatives of potential employers and interested organizations. Only under such conditions the objectivity of the assessment will be ensured, proposed measures for adjusting educational programs, the process of teaching and professional training will be suggested.

Participation of employers in the system of management of quality of higher education makes it possible to change the situation in which the planning of the number of required specialists in certain specialties, the level of their training and the needs of the economy do not coincide. In this aspect, the function of expert councils, with the participation of managers of organizations and interested in graduates of a certain qualification, is a kind of negative feedback on the object of management. Its corrective effect is aimed at reducing the influence of factors that lead to a deterioration in the quality of education. At the same time, the high school's adaptability to external changes increases and the negative influence of the inertia of its development is offset.

As the analysis shows, the objective conditions of social development drive to shift of the emphasis of government from state to public. It should become a powerful stimulus for the development of pedagogical education, contribute to the strengthening of public capacity in management, which, of course, will serve as the driving force for reforming the entire system of pedagogical education. In this context, the adaptation of mechanisms of management of the quality of pedagogical education of Ukraine to international standards creates conditions for the formation of a new system of relations with the public, social partners, employers, and local self-government bodies, which ultimately forms a culture of quality assurance.

The transition to a new paradigm of management of quality of pedagogical education requires a change in consciousness, culture and ways of activities of not only managers, but all employees of the educational establishment. The new school requires a fundamentally new organizational philosophy. The basis of this philosophy is the belief in the personality, the strength of the initiative of employees, the transition from individual and functional activities to the command and cross-functional ones. In practice, the new school demonstrates the benefits of delegation of authority from directors to direct performers, team leaders, and encourages their initiative. The basic principles of management at such a school are openness, transparency, the development of vertical and horizontal information flows, network interaction. 
It is known that the effectiveness of educational processes, in particular, educational activities, largely depends on how competently the managerial component of didactic work, managerial culture, non-conflict management of human resources, awareness of managerial functions is implemented by the manager, since managerial culture characterizes the manager's professional image. It should be understood that the development of the management system not in all EU countries corresponds to the level of development of the object of management. In this context, one should take into account the fact that in these countries there are processes of transformation of national thinking into continental, which makes the traditional cult of the nation secondary.

Scientists and practitioners have proved that the higher the level of continuity of managerial influences is, the higher the effectiveness of management results is; the more stable the rhythm of management is, the higher the organization of the management system and more effective its activity is, since management is the activity over the activity.

In comparison with the countries of the world that have reached a high level of development through the processes of interpenetration of education into the economy, the latest technologies, the social sphere, the current system of pedagogical education of Ukraine functionally still weakly influences social development.

The discrepancy of the public inquiry about the results of pedagogical education and its actual proposals gives little encouraging predictions about the effectiveness of the processes involved in the development of the country. It is not enough to have declared intentions in documents. To do this, we must intensify the processes of qualitative changes in the content of education.

The uniting of European countries by Bologna Agreement requires the search for adaptive and unified methods of managing the quality of pedagogical education, introducing certain changes to them agreed upon with the European community, identifying the best among the available ones, and, if necessary, creating new methods based on generally accepted in Europe standards and rules, which would ensure the implementation of the main tasks of building an open European higher education space.

Improving the effectiveness of training specialists in the context of reforming the domestic system of higher pedagogical education involves rethinking of the purpose and the result of education; updating the content of pedagogical education through the introduction of a new generation of industry standards, based on a competence approach, which is important for providing the quality of education. In addition, the new generation of industry standards offers tools for transferring this approach to educational programs.

As it is shown in scientific studies, the philosophy of quality lies in the fact that the standard of living in the country is determined by the level of quality of products and services provided. Managing the quality of higher pedagogical education is a multifaceted problem, so it can't be argued that it has a purely managerial or pedagogical character. Separate applied but non-systematic efforts to ensure the quality of higher education cannot be effective without a credible philosophical basis created within the philosophy of education, the philosophy of management, which is now being further developed. One of the main problems of the philosophy of education is the problem of constituting education as a mechanism of the development of mankind, the problem of finding ways of advanced development of the system of education and mechanisms of its influence on other social structures.

However, the issues of the essence and content of management of quality of future teachers' training as one of the types of social management, specific ways of solving the problem of the quality of Ukrainian higher education, the awareness of which should affect 
its position in Europe and in the world, remain poorly researched. There is a rather important problem of reviewing the provisions of management and educational management, developing a new modern methodology of management activities, adapting mechanisms of management of quality of Ukrainian pedagogical education to the standards of European countries.

Methodological principles of management of quality of higher education as one of the types of management in accordance with the modern theory of science and the field of management require permanent development and revision. Domestic researchers see the essence of governance in "the formation and implementation of purposeful managerial influences on people, their groups and social processes, which in their aggregate form the social system, as well as the impact on the course and nature of the joint activities of people in order to ensure compliance with the nature and desired results of this activity to certain, pre-selected strategic goals and objectives (Marmaza, 2004, pp. 98-99).

The object of management in this case was the motivation of employees and their relationships in small groups, management strategies were developed on the basis of extrapolation of experience in the future. The study of existing concepts and management theories shows that the development of conceptual approaches, principles and organizational structures of management goes from formal, rigid, centralized to flexible, constructed taking into account the development of democratic processes. As you know, the specificity of management activity is that, performing a certain set of functions that make up the content of management and have a clear sequence of their implementation, "it is not a part of the joint activities of people, but it serves as a unique means of its organizing and ensuring the desired effectiveness of this activity (Marmaza, 2004).

Therefore, it is logical to consider management of quality of pedagogical education as one of the types of social management, the object of which is the system of pedagogical education of Ukraine and participants of this process.

From the standpoint of the theory of systems and system analysis the management of quality of pedagogical education should be considered as a holistic, open, socio-pedagogical system that meets all the characteristic features of complex systems (Gnyezdilova, 2013, p. 111). Systemic, personally oriented and dialogical approaches to the theory and practice of management involve taking into account "trends in the development of pedagogical education, the influence of the environment on managed processes; modeling of integral pedagogical and managerial structures that synthesize a spontaneous and organized beginning; the use of dialogic forms of interaction, etc." (Rahmenvereinbarung über die Ausbildung, 2013, p. 139).

Management of the quality of pedagogical education is defined as one of the types of management, the subject of which is the quality of higher education as a system, process and result, and as an independent part (directions) of the general process of management of higher education.

In such a status, management of quality defines the purpose, policy in the field of quality of pedagogical education and responsibility, which, in its turn, is achieved through the implementation of appropriate management mechanisms and other means, covers quality planning, its provision, operational management, evaluation, processes of improving the quality of higher education in terms of existing quality systems. At the same time, we consider the policy in the sphere of quality of higher education as a system of formation and implementation of targeted mutually agreed national, interregional, regional and local doctrines, strategies, concepts, programs and measures that are systematically implemented by governing bodies, state and independent institutions, representatives of the public and 
aimed at achieving the public goal, i.e. to provide the country with a competitive quality of higher education that will make it possible to improve the quality of life of its citizens (Pazenyuk, 2003). The management of the quality of higher education is manifested in the joint, mutually agreed and complementary activity of state and non-state bodies, public institutions, associations, and public entities with an appropriate division of rights, duties, powers and responsibilities for their implementation between subjects of management, the subject of which is the competitive quality of higher education (as a system, process and result) and its relevance to actual and perspective needs of the individual.

One of the key factors for the success of the development of countries-world leaders, which are the United States, Japan, Germany, and countries that are now striking the world by their pace of development, which are China, India, Brazil, and South Korea is the proper attention of their governments to the issues of education and science.

Adapting the mechanisms of management of quality of Ukrainian pedagogical education to international standards enables, in its turn, to predict, plan and control changes of external environment around the system and the process of higher education. As it is known, the management of higher education is regulated by socio-economic, socio-political, market, social-managerial and other mechanisms of its development. Taking into account the modernization of economic structures, the specific features of market conditions, management of quality of higher education should be a flexible system of methods and principles of efficiency improvement, development of managerial labor.

We emphasize that in management one of the most important imperatives both for the subject and for the object of managerial influence is professionalism. Its level is evaluated from the standpoint of the effectiveness of managerial influence, the maximum achievement of the goal with minimal costs and losses. In conditions of increasing the general cultural and educational level of the population, the organizational dominant in social management is the human factor not only as a factor of the efficiency of production, but also as a prerequisite of a significant reserve of the further successful development of society (Panasyuk, \& Chernyashchuk, 2016, pp. 163-171; International Standard, 1994).

Thus, the development of management of quality of higher education requires deepening of scientific knowledge in this and related fields, since the very essence of management, its tasks, content, characteristics are changing. Summing up the mentioned above, one can conclude that, despite a certain history, humanity only approaches the knowledge and practical creation of democratic, rational, effective management, since for the first time it has approached to such a state, when the problems and processes that provide them went beyond territorial and national boundaries, i.e. they have acquired a global scale (Panasyuk, \& Chernyashchuk, 2016, pp. 22-26).

Important is researchers' opinion that the attitude to knowledge clearly determines the direction of development of the world community and the ability of each country to occupy a certain place in the ranking of developed countries, and fixing the presence of a lack of knowledge in one or another country should make its managers focus on the presence of acute management crisis in the country.

"Thus, the lack of knowledge can be considered as a problem of its deficit, the solution of which is the paramount moment of the forms and pace of the country's entry into the modern world socio-cultural structure. If so, not information as such, but scientific philosophical knowledge is a strategic basis of the development of management of quality of higher education" (Panasyuk, \& Chernyashchuk, 2016, pp. 82-92).

One of the cornerstone reasons of low efficiency of management as one of the types of social management in Ukraine is the very slow development of management education: 
sciendo Порівняльна професійна педагогіка 9(1)/2019 Comparative Professional Pedagogy 9(1)/2019

a small proportion of managers of all levels with special vocational education, the absence of short-term programs for mastering the basics of modern philosophy of management by heads of higher education management authorities, the lack of internships in the vast majority of faculty members in the governing bodies, a small proportion of successful managers among high school teachers (Panasyuk, \& Chernyashchuk, 2016, pp. 135-140).

The analysis of the state of affairs shows that in Ukraine the tradition of directing efforts to solve tasks determined by the central education body continues to operate, while the desire to transform these tasks into regional and local conditions and needs is rather low. Regional educational policy in the conditions of decentralization of all spheres of society's life should combine the state policy in the field of education provided in this territory with the policy determined by the regional authorities.

The scientific analysis of the state of affairs and own practical experience show that the management of a significant part of the heads of establishments of education of all types and levels in Ukraine is implemented at the reproductive level, when the main thing is that the content and direction of management actions correspond to generally accepted and officially approved techniques and means of organizational work in establishments of education. In the process of implementing management activity at this level of activity, practically does not serve goals that would motivate the search for independent solutions to improve the management system. The head of the establishment of education must first direct efforts at increasing their own professionalism and professional level of practical activity. In this approach, you can identify new types of behavior of a manager of a comprehensive establishment:

- innovative-and-reproductive;

- innovative-and-creative.

In the latter management experience is transformed into professional-and-personal qualities, the principles of "high demands and high support" dominate.

Ukrainian educators need to create a mechanism of "translating the requirements of the sphere of work into the language of the sphere of education", to focus on learning outcomes rather than learning. This means: the need to integrate education of Ukraine into the world educational system while preserving the development of the traditions of the Ukrainian school; continuity of the process of obtaining education; decentralization of education management; variability of education, which creates conditions for the free choice of forms and methods of teaching, curricula, programs, specialization.

Based on this, the effectiveness of the managerial component for the implementation of the identified tasks should be determined by: the number of teachers who work according to the new technology; availability of teaching-and-methodological support for the discipline in the specialty; international cooperation; the number of foreign international projects in which an establishment of education is involved; the number of students sent abroad for studying and internship; the number of students who participated and won in international student olympiads, competitions.

In other words, the managerial component must be transformed into professionaland-personal qualities.

In accordance with the National strategy for the development of education of Ukraine for the period of 2012-2021, the Concepts of the development of education of Ukraine for the period of 2015-2025, in the new Law of Ukraine "On Education", the training of modern leaders of the educational branch of Ukraine has been updated. 
Thus, the National strategy for the development of education of Ukraine for the period of 2012-2021 states that the modernization of the education management system involves the optimization of state administrative structures, the decentralization of education management; redistribution of functions and powers between central and regional education authorities, local self-government bodies and establishments of education; development of a system of measures (normative, scientific-and-methodical, financial-andeconomic, etc.) concerning the implementation of the idea of autonomy of establishments of education (On the National Strategy, 2013).

According to the Concepts of the development of education of Ukraine for the period of 2015-2025, it is envisaged to reorganize the system of financing and management of education through decentralization, deregulation, introduction of institutional, academic and financial autonomy of establishments of education, observance of the principle of the responsibility of establishments of education for the results of educational and upbringing activities (On the National Strategy, 2013). All these changes are laid down in the new Law of Ukraine "On Education".

A transition from administrative-and-managerial management to the system of educational management; the introduction of school-based management, the shift of the "center of gravity" in the decision-making process to the operational level (school level) is laid in the field of management.

In this case, the Bologna process as a kind of adaptation mechanism, the movement of educational systems to the common criteria and standards that are being created in Europe, must play an important role. Its main goal is to consolidate the efforts of the scientific and educational community, and the efforts of governments to significantly increase the competitiveness of European higher education. In this context, the top priority of Ukrainian higher education is its fastest adaptation to the single European criteria and standards.

\section{CONCLUSIONS}

The presence of these problems does not indicate their integrity, but rather the lack of methodological understanding of the concepts of innovative development of education and the management of a new school that forms trends in the theory and practice of educational management. The unity of the theory and practice of educational management, their mutual complementation and enrichment will prevent us from wandering in the dark, from the method of trials and errors, will allow to organize and implement an effective, conscious transformation of the educational system into an innovative structure that provides high and competitive quality of Ukrainian education.

Thus, the adaptation of higher pedagogical education of Ukraine to international standards actualizes the study of the experience of those European countries that have made some progress as for the unification of their educational systems to the modern European model, and also successfully use new principles and methods of higher education. Taking into account the similarity of changes in the education of European countries and the transformations that are taking place today in the national system of pedagogical education, the generalized, theoretically meaningful experience of the introduction of the first can be valuable for Ukraine.

\section{REFERENCES}

1. The system of education in Ukraine: the state and prospects of developments (Razumkov Centre analytical report). (2002). National Security of Defense, 4, 2-36. 
2. Dombrovska, S. M. (2013). State Mechanisms for Management of Quality of Higher Education. Management, 2, 54-59.

3. Chmil, A. I. (2006). Principles of Forming the System of Management of Quality of education in the Conditions of Reform. Postgraduate Education in Ukraine, 2 (9), 75-76.

4. Korovkin, M. V. (2005). System of management of quality in the higher educational establishment. Engineering Education, 3, 62-73.

5. Musiyenko, I. I. (2010). Principal Differences of the Education System of Ukraine from the Requirements of the European Space of Higher Education. Scientific papers. Governance, 135, 147, 28-31.

6. Marmaza, O. I. (2004). Innovative Approaches to the management of an educational establishment. Kharkiv.

7. Gnyezdilova, K. M. (2013). Questions of the study of the components of the corporate culture of the teacher of higher school. Scientific Treasury of the Education of Donetsk Region, 2, 32-36.

8. Rahmenvereinbarung über die Ausbildung und Prüfung für ein sonderpädagogisches Lehramt (Lehramtstyp 6) (Beschluss der Kultusministerkonferenz vom 06.05.1994 i.d.F. (2013). Berlin, Bonn: Kultusministerkonferenz.

9. Pazenyuk, V. G. (2003). Synergetics in the context of the emergence of a new ideological paradigm. Higher Education of Ukraine, 3, 29-37.

10. Panasyuk, N. L., \& Chernyashchuk, N. L. (2016). Analysis of the educational system of management of quality of training of future engineers-teachers. Scientific Notes of Volodymyr Hnatyuk Ternopil National Pedagogical University, 1, 163-171.

11. International Standard ISO 8402: Quality Management and Quality Assurance: Dictionary. (1994).

12. On the National Strategy of the Development of Education in Ukraine until 2021. (2013). Retrieved from http://zakon2.rada.gov.ua/law/show/344/2013. 